\title{
Expression and Differential Regulation of Natriuretic Peptides in Mouse Macrophages
}

\author{
Angelika M. Vollmar and Rüdiger Schulz \\ Institute of Pharmacology, Toxicology and Pharmacy, University of Munich, D-80539 München, Germany
}

\begin{abstract}
The coexpression of the natriuretic peptides ANP, BNP and CNP as well as their differential regulation in mouse macrophages was demonstrated by quantitative PCR, HPLC analysis, and specific radioimmunoassays. Exposure of peritoneal- and bone marrow-derived macrophages to various immunomodulators revealed that bacterial LPS strikingly increases (up to 300-fold) the mRNA coding for CNP as does zymosan (up to 15-fold). In this respect, neither the phorbol ester PMA nor the glucocorticoid dexamethasone had any effect. Examination of macrophages for ANP mRNA showed a similar response to LPS and zymosan, though only a three- to sixfold increase, confirming previous data. In contrast, the concentration of mRNA coding for brain natriuretic peptide in these cells was reduced by dexamethasone (up to twofold) as well as LPS (two- to fivefold). No change was observed upon challenge with zymosan or PMA.

The findings at the mRNA level are complemented by their corresponding peptide products. Incubation of macrophages with LPS resulted in a two- and fivefold elevation of intracellular ANP and CNP immunoreactivity, respectively. The amount of peptides released from cells under these conditions was found increased for ANP (threefold) and CNP (10-fold). No changes were observed for both intra- and extracellular brain natriuretic peptide. The coexpression of natriuretic peptides in macrophages as well as their different regulations by immunomodulators suggest discrete functions of these peptides within the immune system. (J. Clin. Invest. 1995. 95:2442-2450.) Key words: atrial natriuretic peptide $\cdot$ brain natriuretic peptide $\bullet$ C-type natriuretic peptide $\cdot$ polymerase chain reaction $\cdot$ immune system
\end{abstract}

\section{Introduction}

Natriuretic peptides (NP) ${ }^{1}$ deduce from a gene family which comprises the atrial natriuretic peptide (ANP), the brain natri-

Address correspondence to Angelika M. Vollmar, Ph.D. Institut für Pharmakologie, Toxikologie, und Pharmazie, Königinstrasse 16, D80539 München, Germany. Phone: 49-89-802665; FAX: 49-89-342316. 1995.

Received for publication 3 June 1994 and in revised form 12 January

1. Abbreviations used in this paper: 8-Br-cGMP, 8-bromo-cGMP; ANP, atrial natriuretic peptide; BMM, bone marrow-derived macrophages; BNP, brain natriuretic peptide; CNP, C-type natriuretic peptide; Dex, dexamethasone; gDNA, genomic DNA; IR, immunoreactivity; NP, natriuretic peptide; PM, peritoneal macrophages; RT-PCR, reverse transcription PCR; TFA, trifluoracetic acid.

J. Clin. Invest.

(c) The American Society for Clinical Investigation, Inc.

0021-9738/95/06/2442/09 \$2.00

Volume 95, June 1995, 2442-2450 uretic peptide (BNP), and the C-type natriuretic peptide (CNP) $(1,2)$. Although the number of their amino acids varies from 22 to 45 (ANP99-126, BNP-45, CNP-22), they share a 17 amino acid ring structure which proved essential for the interactions with their individual receptors $(1-3)$. While ANP and BNP preferentially activate the A-type NP receptors, CNP is considered to represent the natural ligand for the B-type receptor $(3,4)$. Each peptide is capable of binding to the C-type NP receptor $(3,4)$. These features as well as the distinct distribution of the NP receptors throughout the body prompted speculations on integrated mechanisms of NP to control distinct biological functions including volume homeostasis (1-4).

Endogenous substances are often termed by their location within the body, at the time of discovery, or by their biological actions first defined. The NP were originally detected in the heart atrium (ANP) or the brain (BNP, CNP), and were found to elicit renal as well as vasoactive effects (1-4). Meanwhile NP have been discovered in many tissues throughout the body $(1,2,5-8)$, and additional functions have been documented $(1,2,5,9)$.

These findings have been extended by recent reports suggesting that ANP represents a constituent of the immune system. This peptide affects the function of phagocytes and natural killer cells $(10,11)$, and is expressed in various immune organs, including the thymus $(5,12,13)$.

Moreover, involution of the rat thymus brought about by either dexamethasone (Dex) or X-rays results in a considerable increase of ANP synthesis $(14,15)$, which has been shown to be attributed to an activation of thymic macrophages $(15,16)$. A similar phenomenon has been observed in cultured peritoneal (PM) and bone marrow-derived macrophages (BMM) stimulated in vitro by specific immunomodulators (17).

Coexpression of NP has been reported for certain cells such as single multipotential cardiac myocytes which are able to synthesize both ANP and BNP $(18,19)$, or hypothalamic neurons containing ANP and CNP (20). In addition, individual regulation of cardiac NP has been communicated $(21,22)$.

The question as to whether these observations also apply to NP expression in immune cells was the subject of the present study. Cultured PM and BMM were examined for the expression of BNP and CNP, in addition to ANP (17). Emphasis was given to whether the expression of the NP underlies different regulatory mechanisms. The macrophages were incubated with various agents known to affect their function, and the effects on the corresponding mRNA expression as well as peptide production was studied by use of competitive PCR and HPLC analysis combined with radioimmunological methods.

\section{Methods}

Purchased materials. Medium, FCS, thioglycollate broth, and penicillin/streptomycine (GIBCO BRL, Peasley, United Kingdom); phenolextracted Escherichia coli LPS (serotype 055), PMA, zymosan, cyto- 
chalasin-B, dextran sulfate, 8-bromo-cGMP (8-Br-cGMP) (Sigma Chemical Co., St. Louis, MO); FITC-labeled antiserum against the macrophage antigen F40/80 (Serotec Canon, Wiesbaden, Germany); fluorescent latex particles (Polysciences, Inc., Warrington, PA); Dexamethasone solution ( $4 \mathrm{mg} / \mathrm{ml}$ ) (Centravet, Bad Bentheim, Germany); rat ANP 99-126, rat BNP-32, BNP-45 and porcine CNP-22, $-53,{ }^{125} \mathrm{I}-$ CNP-22 and ${ }^{125}$ I-BNP-32, anti-rat BNP antiserum, and anti-porcine CNP (Peninsula Laboratories Inc., Belmont, CA); ${ }^{125}$ I-rat ANP (Amersham International, Braunschweig, Germany); mRNA purification kit Polytract, reverse transcription (RT) system kit, Thermus aquaticus (Taq) DNA polymerase and mouse genomic DNA (gDNA) (Promega/ Serva, Heidelberg, Germany); $\left[\alpha-{ }^{32} \mathrm{P}\right] \mathrm{dCTP}, 3,000 \mathrm{Ci} / \mathrm{mmol}$ (Hartmann Analytic, Braunschweig, Germany); SepPak $\mathrm{C}_{18}$ cartridges, reverse phase HPLC $\mu$ Bondapak columns (Waters, Milford, United Kingdom); glass fiber filters (Whatman Inc., Maidstone, United Kingdom). Anti-ANP antiserum Toni V (12) was kindly provided by Dr. R. M. Arendt, University of Munich, Germany.

Collection and cultivation of mouse primary macrophages. Bone marrow cells were flushed with RPMI 1640 medium from the femurs of BALB/c mice (female, 20-30 g). Cells $\left(2 \times 10^{5}\right.$ cells $\left./ \mathrm{ml}\right)$ were seeded (175 $\mathrm{cm}^{2}$ flasks; Greiner, Solingen, Germany) and cultured $\left(37^{\circ} \mathrm{C}, 5 \% \mathrm{CO}_{2}\right)$ in RPMI 1640 medium, containing $20 \%$ (vol/vol) L929 cell-conditioned medium as source of the macrophage growth factor (23), 10\% FCS, and penicillin ( $100 \mathrm{U} / \mathrm{ml}) /$ streptomycin $(100 \mu \mathrm{g} / \mathrm{ml})$. To eliminate contaminating fibroblasts, nonadherent bone marrow cells were transferred after $24 \mathrm{~h}$ to new flasks and grown in the abovementioned medium for 5-6 d. L-929 cell-conditioned medium and FCS were removed at least $12 \mathrm{~h}$ before stimulation of cells with LPS $(0.1-$ $10 \mu \mathrm{g} / \mathrm{ml})$, PMA $\left(10^{-7} \mathrm{M}\right)$ zymosan $\left(10^{6} \mathrm{cells} / \mathrm{ml}\right)$, and Dex $\left(10^{-7}\right.$ $M)$, respectively. In a further set of experiments cells were exposed to either dextran sulfate (DS) $(10 \mu \mathrm{g} / \mathrm{ml})$, LPS $(1 \mu \mathrm{g} / \mathrm{ml})$, a combination of both, cytochalasin-B $(25 \mu \mathrm{g} / \mathrm{ml})$, zymosan $\left(10^{6}\right.$ cells $\left./ \mathrm{ml}\right)$, zymosan plus cytochalasin-B, or 8-Br-cGMP $\left(10^{-4} \mathrm{M}\right)$. For RT-PCR experiments cells were stimulated for $2,4,6,18$, and $30 \mathrm{~h}$, respectively, depending on the type of experiment. Macrophages used for peptide extraction were treated for $24 \mathrm{~h}$.

PM were collected by abdominal lavage (ice-cold PBS) from mice treated with thioglycolate broth (intraperitoneally, $1 \mathrm{ml}, 4 \%$ ) $4 \mathrm{~d}$ before cell harvest. PM were washed and resuspended $\left(10^{5} \mathrm{cells} / \mathrm{ml}\right)$ in RPMI 1640 medium (10\% FCS). $2 \mathrm{~h}$ after seeding cells $\left(175 \mathrm{~cm}^{2}\right.$ flasks) nonadherent cells were removed. FCS was withdrawn at least $6 \mathrm{~h}$ before exposure of the cells to the various agents.

BMM and PM were found $>98 \%$ pure as judged by FACS ${ }^{\oplus}$ analysis (Becton Dickinson and Co., San Jose, CA), using the FITC-labeled antiserum against the macrophage antigen $\mathrm{F} 40 / 80$ as previously described (17). Their functional activity was assessed by flow cytometric analysis of phagocytosis (fluorescent latex particles) (24).

mRNA extraction. Total cytoplasmatic RNA of macrophages was extracted by the guanidinium-thiocyanate/cesium chloride method (25). The integrity of RNA preparations was confirmed after electrophoresis on agarose gels. RNA quantification was conducted by ultraviolet (UV) $(260 \mathrm{~nm})$. mRNA was isolated by oligo dT-adsorption of total cellular RNA (PolyAtract ${ }^{\mathrm{TM}}$ Isolation System; Promega/Serva) and quantified both by UV $(260 \mathrm{~nm})$ and dot blot hybridization to end labeled $\mathrm{p}(\mathrm{dT})_{12-18}(7)$.

cDNA synthesis. $1 \mu \mathrm{g}$ mRNA was mixed with $\mathrm{p}(\mathrm{dT})_{12-18}(0.5 \mu \mathrm{g})$, $20 \mathrm{U}$ of RNA ribonuclease inhibitor, $1 \mathrm{mM} \mathrm{dNTP,} 5 \mathrm{mM} \mathrm{MgCl}_{2}$ in 10 $\mu l$ transcription buffer ( $10 \mathrm{mM}$ Tris $\mathrm{HCl}, 50 \mathrm{mM} \mathrm{KCl}, 0.1 \%$ Triton X100 ) before adding $15 \mathrm{U}$ avian myeloblastosis virus reverse transcriptase (Reverse Transcription System Kit; Promega/Serva) and incubating for $20 \mathrm{~min}$ at $42^{\circ} \mathrm{C}$. For estimation of efficiency of transcription an aliquot $(4.5 \mu \mathrm{l})$ of the reaction mix was incubated with $1 \mu \mathrm{Ci}$ of $\left[\alpha{ }^{32} \mathrm{P}\right] \mathrm{dCTP}$ $(3,000 \mathrm{Ci} / \mathrm{mmol})$. Thereafter samples were heated $\left(95^{\circ} \mathrm{C}, 5 \mathrm{~min}\right)$ and then quickly chilled on ice. The amount of synthesized cDNA was estimated by the amount of $\left[\alpha-{ }^{32} \mathrm{P}\right] \mathrm{dCTP}$ incorporated, which was determined after separation of free dCTP. Separation was achieved by precipitation with TCA (5\%) and filtration (glass fiber filters, GF/B). Efficiency of cDNA synthesis varied between 40 and $80 \%$. cDNA content has been equalized, samples were diluted to $10 \mathrm{ng} / \mu \mathrm{l}$ in PCR buffer ( $20 \mathrm{mM}$ Tris $\mathrm{HCl}$, pH 8.3, $50 \mathrm{mM} \mathrm{KCl}, 1.5 \mathrm{mM} \mathrm{MgCl}_{2}, 0.01 \%$ gelatin ), and stored at $-20^{\circ} \mathrm{C}$.

Oligonucleotides used for PCR amplification. HPLC-purified oligonucleotides were obtained from MWG, (Ebersberg, Germany). For ANP mRNA amplification a sense primer ( 5 '-CAGCATGGGCTCCTTCTCCA-3') and an antisense primer ( $5^{\prime}$-TCCGCTCTGGGCTCCAATCCT-3') (21) corresponding to sequences in the first and second exon of the mouse ANP gene (26), were used. The sense primer ( $5^{\prime}$-CTGAAGGTGCTGCCCCAGATG-3' $)$ for BNP is localized in the first exon, the antisense oligonucleotide (5'-GACGGATCCGATCCGGTC-3') (21) in the second exon of the mouse gene (27). The primers for amplification of CNP mRNA have been deduced from the rat gene sequence (28) as the mouse sequence has not yet been elucidated. Sense and antisense CNP primers localized in the first and second exon, respectively, possess the following nucleotide sequences: 5 '-CGCACCATGCACCTCTCCCAGCTGAT-3' and 5'-CGCTGCACTAACATCCCAGACGC- $3^{\prime}$. Sequences of primers for murine TNF- $\alpha$ as well as for tubulin have been described elsewhere $(21,29)$.

Amplification method. PCR was performed in PCR buffer $(100 \mu \mathrm{l})$ to which the following components (final concentration) were added: $50 \mu \mathrm{M}$ dNTPs, $1 \mathrm{nM}$ BSA, $0.1 \mu \mathrm{M}$ of each primer, $1 \mu \mathrm{Ci}\left[\alpha^{-32} \mathrm{P}\right] \mathrm{dCTP}$, $2 \mathrm{U}$ of Taq DNA polymerase, and various amounts of cDNA and genomic DNA $(7,17)$. The mixture was overlaid with mineral oil and subjected to 37 cycles of amplification, unless differently noted. The amplification profile consisted of denaturation at $95^{\circ} \mathrm{C}$ for $3 \mathrm{~min}$, primer annealing at $59^{\circ} \mathrm{C}$ for $1 \mathrm{~min}$, and extension at $74^{\circ} \mathrm{C}$ for $3 \mathrm{~min}$. Amplification of TNF- $\alpha$ and tubulin sequences was performed as previously described $(21,29)$. In all PCR experiments the presence of possible contaminants was tested by control reactions in which either cDNA was omitted or mRNA ( $40 \mathrm{ng}$ ), which has not been reverse transcribed, was added. Conditions for linear amplification were assessed as follows: firstly, for each pair of primer (i.e., for amplification of ANP-, BNP-, and CNP-specific mRNA, respectively) increasing amounts of cDNA $(2.5-200 \mathrm{ng})$ and mouse gDNA $(12-5,000 \mathrm{pg})$ were amplified in 37 cycles. Secondly, increasing numbers of cycles (20-50) were run with 40,15 , and 20 ng cDNA combined with 50, 125, and 1,250 pg gDNA for amplification of ANP, BNP, and CNP sequences, respectively.

Quantitative PCR. For relative quantification of PCR products the method of competitive polymerase chain reaction has been used (17, 29,30 ). Briefly, a constant amount of cDNA (ANP, $40 \mathrm{ng}$; BNP, 15 ng; CNP, $20 \mathrm{ng}$ ) and serial dilutions of competitor DNA (mouse gDNA, ANP, 12.5-200 pg; BNP, 16-250 pg; CNP, 0.5-1,000 ng) were amplified in 37 cycles as described above. These conditions (see above) assure quantification of corresponding specific mRNAs in the linear phase of amplification. Each reaction mixture furthermore included [ $\alpha$ $\left.{ }^{32} \mathrm{P}\right] \mathrm{dCTP}(1 \mu \mathrm{Ci})$. Aliquots $(6 \mu \mathrm{l})$ of PCR mixture were submitted to gel electrophoresis ( $6 \%$ acrylamide) and the components were identified by silver nitrate staining followed by exposure to $\mathrm{x}$-ray films $\left(-70^{\circ} \mathrm{C}\right.$, $18 \mathrm{~h}$ ). Products arising from amplification of cDNA or gDNA templates are expected to yield fragments of the following sizes: 430 and $534 \mathrm{bp}$ for ANP-, 321 and 515 bp for BNP-, and 394 and 838 bp for CNPcomprising fragments. The bands were cut into vials, dissolved in $30 \%$ $\mathrm{H}_{2} \mathrm{O}_{2}$, and counted in a $\beta$-counter in the presence of scintillation fluid. PCR amplification of samples has been performed in duplicate and the experiments using independent mRNA preparations were repeated two to three times. A different set of experiments was performed for TNF$\alpha$ expression. After assessing linear amplification conditions, cDNA ( $0.1 \mathrm{ng}, 20 \mathrm{ng}$, and $5 \mathrm{pg}$, respectively) have been used to PCR using either primer for TNF- $\alpha$, CNP, or tubulin ( 35 cycles). PCR products were processed as described above. Experiments based on two independent mRNA preparations were repeated twice.

Preparation of cell medium and extracts. Medium was removed of the cells, acidified ( $\mathrm{pH} 3.0,10 \mathrm{M}$ acetic acid), centrifuged $(15,000 \mathrm{~g}$, $20 \mathrm{~min}$ ), and the clear supernatant stored at $-70^{\circ} \mathrm{C}$. Cells adherent to the surface were washed twice with PBS. Subsequently, $1 \mathrm{M}$ acetic acid $\left(95^{\circ} \mathrm{C}\right.$ ) was added, boiled for $1 \mathrm{~min}$ (microwave), and the lysed cell material was harvested with a rubber policeman. After centrifugation 
$(20,000 \mathrm{~g}, 20 \mathrm{~min})$ the clear supernatant was stored at $-70^{\circ} \mathrm{C}$. Both the cell extracts as well as their media were submitted to SepPak $C_{18}$ cartridges, which were washed with $0.1 \%$ trifluoroacetic acid (TFA), and subsequently eluted with $60 \%$ acetonitrile $/ 0.1 \%$ TFA.

Chromatographic analysis of cell extracts and medium. Reverse phase HPLC analysis of cell extracts $(20 \mathrm{mg}$ protein, $100 \mu \mathrm{l})$ was carried out by means of a $\mathrm{C}_{18}$ Bondapak column $(4.5 \times 2,500 \mathrm{~mm})$. Elution of ANP and BNP material was conducted with a linear gradient of $20-55 \%$ acetonitrile in $0.1 \%$ TFA ( $55 \mathrm{~min}$, flow rate $1 \mathrm{ml} / \mathrm{min}$ ). For separation of CNP a gradient of $15-35 \%$ acetonitrile in $0.1 \%$ TFA (75 $\mathrm{min}$ ) was chosen.

Cell supernatant equivalent to $20 \mathrm{mg}$ cell protein was loaded ( 250 $\mu \mathrm{l})$ on a preparative reverse phase HPLC $(10 \times 2,500 \mathrm{~mm})$ and eluted under conditions as described above except for a flow rate of $3 \mathrm{ml} / \mathrm{min}$. Fractions obtained from either separation were lyophilized and assayed for ANP, BNP, and CNP immunoreactivity (IR). Quantification of NP IR relates to three independent cell preparations both for LPS-stimulated and unstimulated cells. Values are given as means \pm SD and differences in NP levels were evaluated by Student's $t$ test $(P<0.05$, significant differences). Loss of natriuretic peptides due to extraction and separation procedures was estimated by adding radioactive labeled ANP99126, BNP-45, as well as CNP-22 $(\sim 30,000 \mathrm{cpm})$ to cells and medium, respectively, before extraction and chromatographic procedure.

RIA for ANP. ANP-immunoreactivity was measured by RIA (12). The polyclonal rabbit ANP antiserum (Toni V) used showed $<0.01 \%$ cross-reactivity with rat BNP-45, BNP-22, and CNP-22 (unpublished data). Sensitivity of the assay was $1.5 \mathrm{pg} /$ tube.

RIA for BNP. For measurement of BNP immunoreactivity rat BNP32 antiserum (RAS 9085; Peninsula Laboratories Inc.) and rat ${ }^{125}$ I-BNP32 was used, using the identical protocol as given for the ANP-RIA. According to the manufacturer, the antiserum does not recognize mouse ANP. The cross-reactivity to porcine CNP-22 is $<0.1 \%$. Sensitivity of the assay was $9 \mathrm{pg} /$ tube.

RIA for CNP. The protocol followed that described for ANP, using porcine CNP-22 antiserum (RAS 9030; Peninsula Laboratories Inc.) and ${ }^{125} \mathrm{I}-\mathrm{CNP}-22$ (porcine). Cross-reactivities to rat BNP-45, human BNP-32, and mouse ANP have been reported (according to the manufacturer) to be $<0.01 \%$. The lower detection limit of the assay was 3 $\mathrm{pg} /$ tube.

\section{Results}

Detection of NP transcripts in macrophages by RT-PCR. Primary cultures of macrophages were found to be $\sim 95 \%$ pure using flow cytometric analysis of binding of an FITC-labeled antibody against the F40/80 macrophage antigen. Functional activity of cells was assessed by monitoring the phagocytosis of fluorescent microspheres (data not shown).

Cultured PM as well as BMM expressed mRNA coding for ANP, BNP, and CNP. The corresponding PCR amplification products were size-fractionated by PAGE electrophoresis and DNA bands visualized by silver nitrate staining (Fig. 1). Bands of the expected size (ANP $430 \mathrm{bp}$, BNP $321 \mathrm{bp}$, and CNP 394 bp) comigrated with transcripts (positive control) obtained by amplification of cDNA extracted from tissues known to express the NP (heart ventricle, brain). mRNA extracted from BMM, i.e., omitting reverse transcription, did not yield any amplification products (negative control).

Experimental conditions for quantification of PCR products. To determine the optimal conditions for quantitative PCR, optimization of the initial amount of DNA template as well as the number of PCR cycles had to be achieved. cDNA samples ranging from 2.5 to $200 \mathrm{ng}$ cellular mRNA as well as 12.55,000 pg gDNA, depending on the primer pairs used, were subjected to 37 PCR cycles. The yield of DNA has been shown

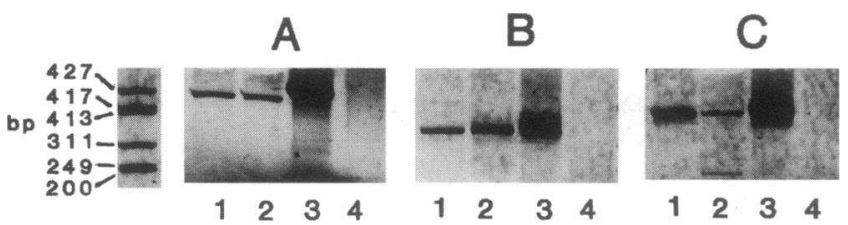

Figure 1. Representative PCR of cDNA sequences coding for ANP $(A)$, BNP $(B)$, and CNP $(C)$ in macrophages. Corresponding amplification products were size fractioned by PAGE and stained by silver nitrate. (A) Lane 1-3 ANP transcripts (430 bp) from cDNA of BMM (40 ng), PM (30 ng), and heart ventricle (1 ng), lane 4: mRNA (40 ng) of BMM. (B) Lane 1-3: BNP transcripts (321 bp) in PM, BMM (15 ng each), and heart ventricles (2 $\mathrm{ng})$, lane 4: mRNA (40 $\mathrm{ng}) .(C)$ Lane 1-3: CNP transcripts in PM (20 ng), BMM (10 ng) and brain ( $5 \mathrm{ng}$ ), lane 4: mRNA (40 $\mathrm{ng}$ ).

to be directly proportional to the initial template concentration as representatively shown for amplification of BNP transcripts in BMM (Fig. $2 A$ ).

Fig. $2 B$ demonstrates a representative experiment for CNP cDNA amplification, indicating that optimal conditions for quantitative PCR amplification can be assumed over a range of 30-40 PCR cycles with an initial template concentration of 20 ng cDNA combined with $1 \mathrm{ng}$ gDNA. Similar results were obtained for amplification of ANP- and BNP-specific templates using 40 and $15 \mathrm{ng}$ cDNA as well as 50 and $125 \mathrm{pg}$ gDNA, respectively (data not shown). The amount of gDNA added to cDNA had to be determined in separate experiments (for each of the three PCR) to assure an approximately equal concentration of competing PCR products derived from cDNA and gDNA, respectively. Ideally, competitor DNA should possess a similar size as the target cDNA to assume equal amplification efficiency. Therefore, it should be stressed that the specific cDNA and gDNA sequences were amplified with similar efficiencies as demonstrated by the similar slopes of curves in Fig. $2, A$ and $B$. Thus, gDNA proved useful as an internal standard template in competitive PCR of NP templates.

mRNAs coding for natriuretic peptides in stimulated macrophages. For the purpose of a relative quantification of mRNAs coding for ANP, BNP, and CNP, both in BMM and PM, after their exposure to various stimuli, competitive PCR analysis was performed. Fig. 3 shows a representative experiment for amplification of BNP $(A)$ and CNP sequences $(B)$ of BMM $(A)$ and PM $(B)$ which had not been stimulated $(C o)$ or stimulated ( $L P S, 18 \mathrm{~h}, 1 \mu \mathrm{g} / \mathrm{ml}$ ). A constant amount of cDNA (BNP 15 $\mathrm{ng}$; CNP $20 \mathrm{ng}$ ) is amplified with serially decreasing amounts of standard gDNA added (CNP 80-0.5 ng ( $\mathrm{Co}$ ), 1,000-62.5 ng (LPS); BNP 0.25-0.016 ng). For the sake of comparison, ANP mRNA expression was also examined in these batches of cells, confirming previous data (17). Competitive PCR amplification was most reliable if the concentration of the amplified standard DNA was within a 10-fold range of the cDNA transcripts. Therefore, the optimum range of gDNA had to be determined for each reaction protocol (ANP, BNP, and CNP mRNA, respectively). With decreasing gDNA concentrations, the signal of the corresponding amplification product (CNP $838 \mathrm{bp}$; BNP $515 \mathrm{bp}$ ) became less intense while the intensity of the target cDNA (CNP 394 bp; BNP 321 bp) increased. Bands were cut, quantified by their amounts of radioactivity, and the PCR product ratios (gDNA/cDNA) were plotted as a function of the initial amount of gDNA (Fig. 4). 

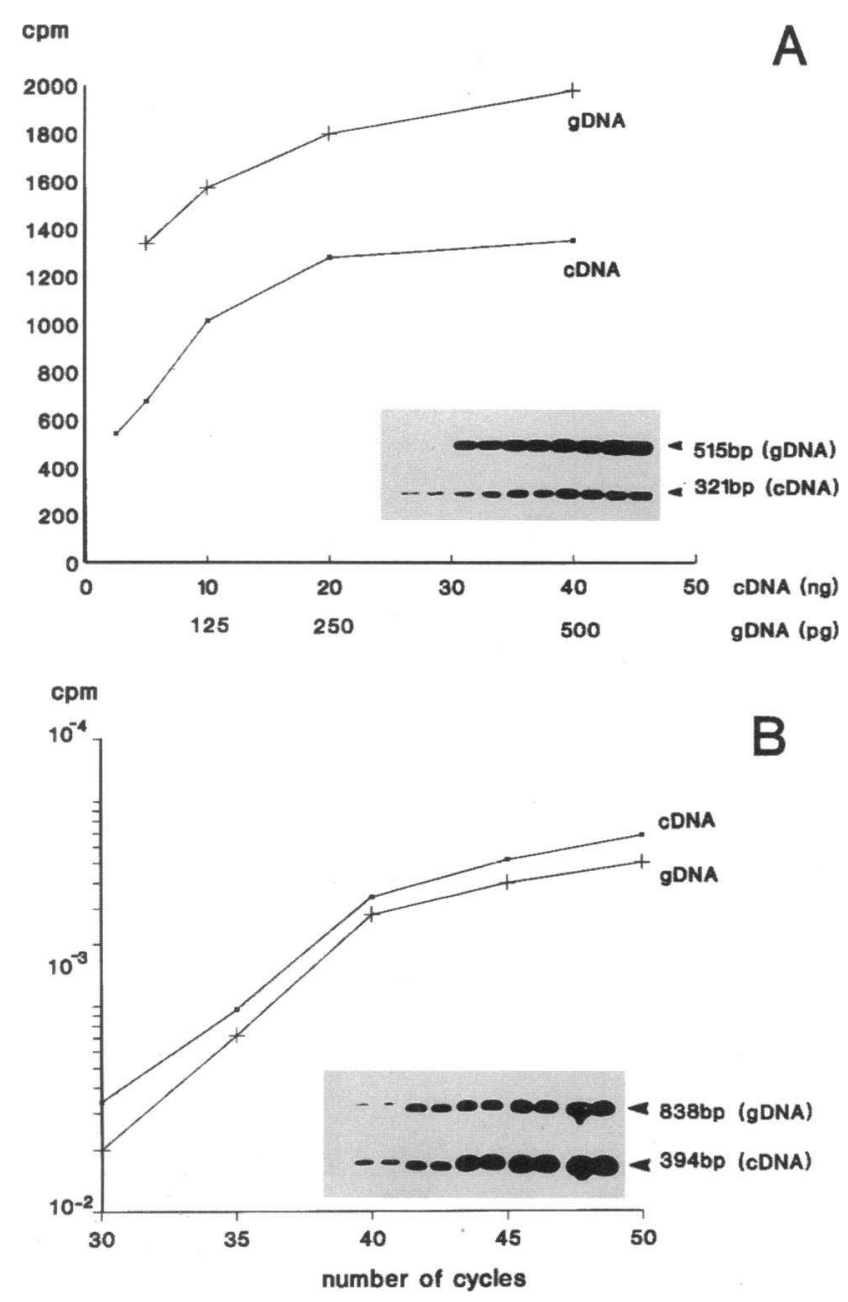

Figure 2. Linear amplification of NP cDNA sequences. $(A)$ cDNA corresponding to 2.5-40 ng mRNA from BMM ( $\square)$ and mouse gDNA $(62.5-500 \mathrm{pg})(+)$ were subjected in duplicates to 37 cycles using the BNP specific primer pair. $(B) \mathrm{cDNA}$ from PM, corresponding to $20 \mathrm{ng}$ mRNA as well as 1 ng gDNA, were subjected to 30-50 PCR cycles. PCR products were separated by PAGE, autoradiographed (insets), and counted for incorporated radioactivity. Mean radioactivity (cpm, $n=2)$ was plotted against concentration of initial templates $(A)$ or against the number of cycles performed $(B)$.

Referring to the equivalence region of the titration curves (ratio of gDNA/cDNA $=1$ ), a shift toward the right or left of the curves obtained from cDNA of stimulated cells indicates increased or decreased amounts of PCR products. As seen in Fig. $4 A$ stimulation of PM with either LPS, zymosan, or a combination of LPS with either zymosan or Dex, elicited a striking increase of CNP mRNA. Exposure to Dex only as well as to PMA showed no effects. Similar results were obtained for BMM.

In contrast, BNP mRNA expression was decreased in PM and BMM (Fig. 4 B) stimulated with LPS, Dex, and LPS/ Dex, respectively. No change in PCR product concentration was observed after exposure of cells to either zymosan or PMA in comparison to untreated cells.

Fig. 5 summarizes the effects of various stimuli on ANP-, BNP-, and CNP-specific mRNA concentrations of BMM $(A)$ as well as PM $(B)$. LPS $(1 \mu \mathrm{g} / \mathrm{ml}, 18 \mathrm{~h})$ and zymosan $\left(10^{6}\right.$
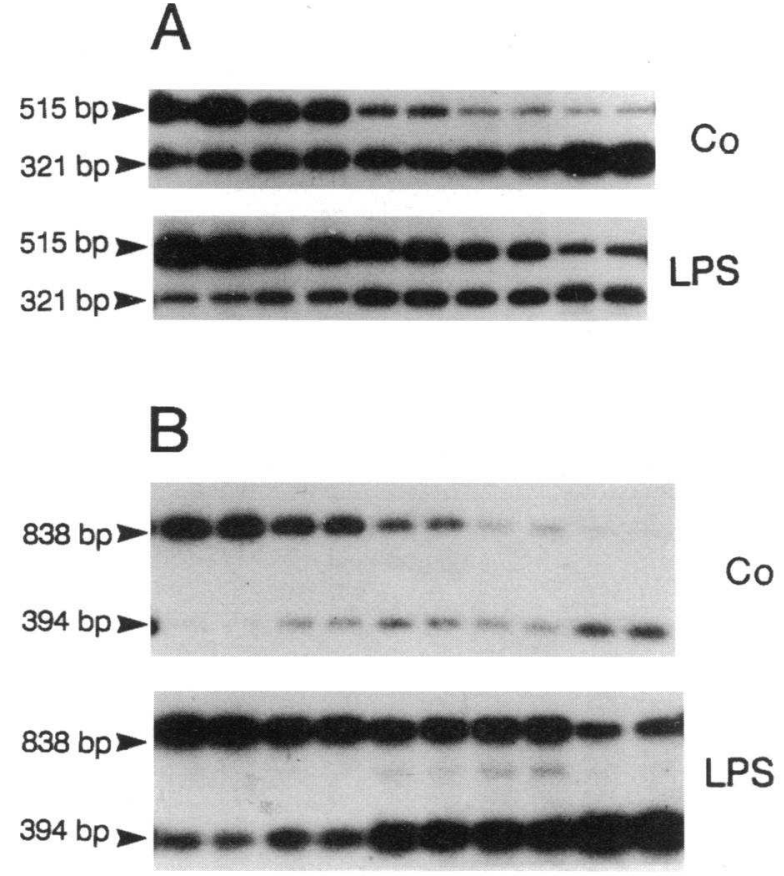

Figure 3. Representative competitive PCR amplifying BNP- $(A)$ and CNP- $(B)$ specific templates of cDNA ( $15 \mathrm{ng} ; 20 \mathrm{ng}$ ) of untreated BMM (BNP) and PM (CNP), and cells incubated with LPS $(1 \mu \mathrm{g} / \mathrm{ml}, 18 \mathrm{~h})$. Decreasing amounts of gDNA were coamplified (CNP 8-0.5 ng (Co) and 1000-62.5 ng (LPS); BNP 0.250-0.016 ng). Amplification and separation by PAGE were carried out as described in Methods. PAGE gels were exposed to $\mathrm{x}$-ray films for $18 \mathrm{~h}$ at $-70^{\circ} \mathrm{C}$. Co, untreated cells.

cells $/ \mathrm{ml}, 4 \mathrm{~h}$ ) bring about a 40-fold and 12.5-fold increase in CNP mRNA in BMM, respectively, and an even more striking 300-fold and 15-fold elevation in PM. PMA as well as Dex only moderately affect CNP mRNA in both cell types. BNP mRNA of PM was not substantially elevated by PMA or Dex neither by zymosan or zymosan/LPS. However, it was reduced by LPS (twofold) and Dex/LPS (2.5-fold). Incubation of BMM with PMA, zymosan, and zymosan/LPS, respectively, only slightly affected BNP mRNA concentration, whereas Dex, Dex/LPS, and LPS lowered the concentration by 2-, 2.5-, and 5.5-fold, respectively. The stimulatory effect on ANP mRNA of these PM as well as of BMM confirmed published data (17), i.e., LPS: 2- and 2.5-fold; Dex/LPS: 2.3- and 3-fold; zymosan: five- and sixfold.

Further experiments were performed to address possible mechanisms underlying stimulation of NP gene expression. The involvement of scavenger receptors (31) in CNP stimulation evoked by LPS was one hypothesis to be tested. Cells were exposed to dextran sulfate, known to block this type of receptors. However, as shown in Fig. $6 \mathrm{~A}$, addition of dextran sulfate did not attenuate the effect of LPS on CNP mRNA expression in BMM. However, use of an inhibitor of the cytoskeleton, such as cytochalasin-B $(31,32)$, was able to reduce the increase of CNP mRNA concentration caused by zymosan. Thus, activation of phagocytosis, being at least partly responsible for CNP stimulation, is suggested.

On reverse, increased CNP and ANP concentrations might be acting to down-regulate expression of BNP. Incubation of cells with the second messenger of NP, namely cGMP (8-Br- 


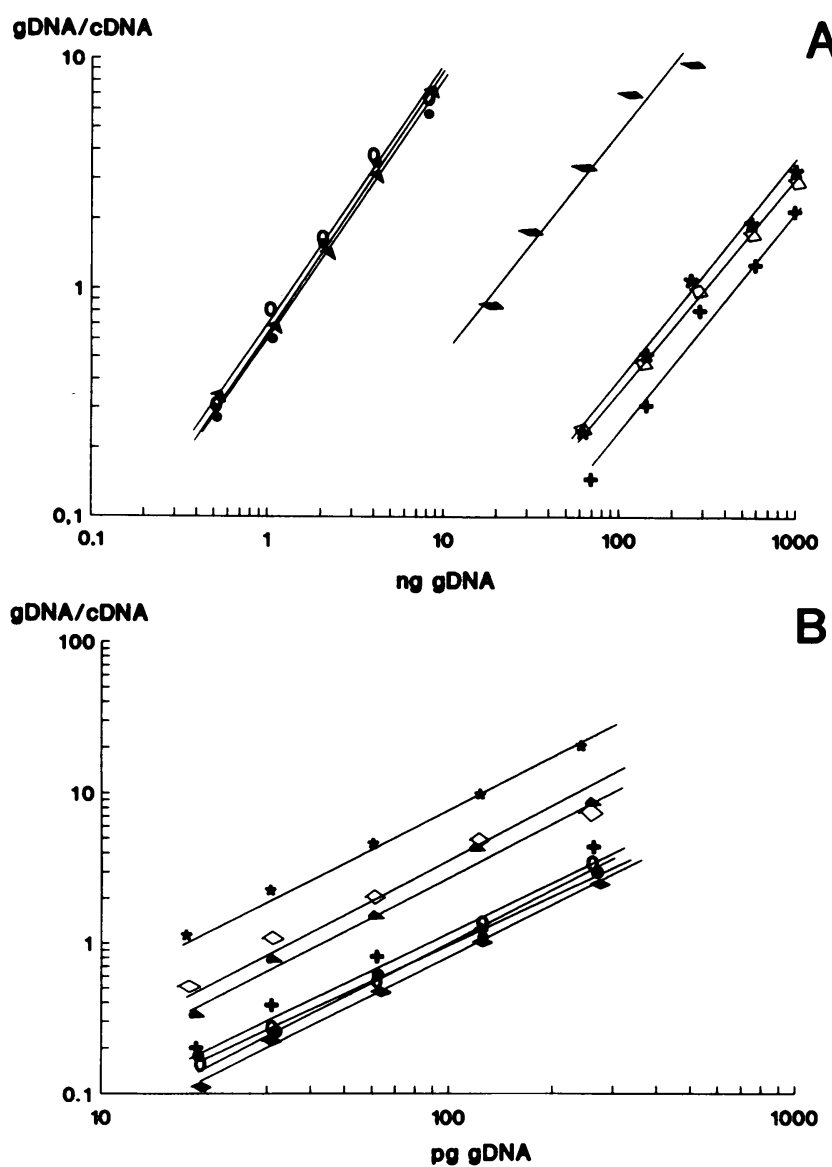

Figure 4. Titration curves of cDNA from untreated cells $(\bullet)$, cells incubated with LPS $(\star)$, zymosan $(\bullet)$, Dex $(\Delta)$, PMA (O), LPS and Dex $(\diamond)$, and zymosan and LPS (+) for amplification of CNP $(A)$ and BNP $(B)$ sequences. Data were obtained by cutting the corresponding bands of PAGE gels visualized with silver nitrate and counting the radioactivity incorporated in the PCR products. The ratio of gDNA/ cDNA related radioactivity is plotted on a $\log -\log$ scale against the amount of gDNA. Values represents the mean of three independent mRNA preparations, thereby each PCR reaction product was subjected in triplicates to PAGE and mean values were used.

cGMP, $10^{-4} \mathrm{M}$ used), however, did not alter BNP mRNA expression (Fig. $6 \mathrm{~B}$ ).

The distinct regulation of mRNAs coding for CNP and BNP might also be due to individual kinetics of the mRNA expression and to the concentrations of stimulants used. Therefore, macrophages were exposed to different concentrations of LPS $(0.1$, 1 , and $10 \mu \mathrm{g} / \mathrm{ml}, 18 \mathrm{~h}$ ) and treated for different time intervals $(6,18$, or $30 \mathrm{~h})$. Stimulation for $18 \mathrm{~h}$ elicits maximal concentrations of mRNA expression for ANP and CNP. The maximal decrease in mRNA concentration coding for BNP was established after $30 \mathrm{~h}$ (Fig. $7 A$ ). In either case $1 \mu \mathrm{g} / \mathrm{ml}$ LPS appears to maximally affect mRNA levels of the three peptides (Fig. $7 \mathrm{~B}$ ).

Stimulation of NP by LPS may furthermore be mediated by cytokines known to be released after challenge of macrophages with LPS $(33,34)$. Fig. 8 shows the time course of CNP expression in relation to TNF- $\alpha$ gene expression. Synthesis of TNF$\alpha$ mRNA by BMM already reached maximal level $2 \mathrm{~h}$ after LPS exposure, a time point where CNP mRNA transcription
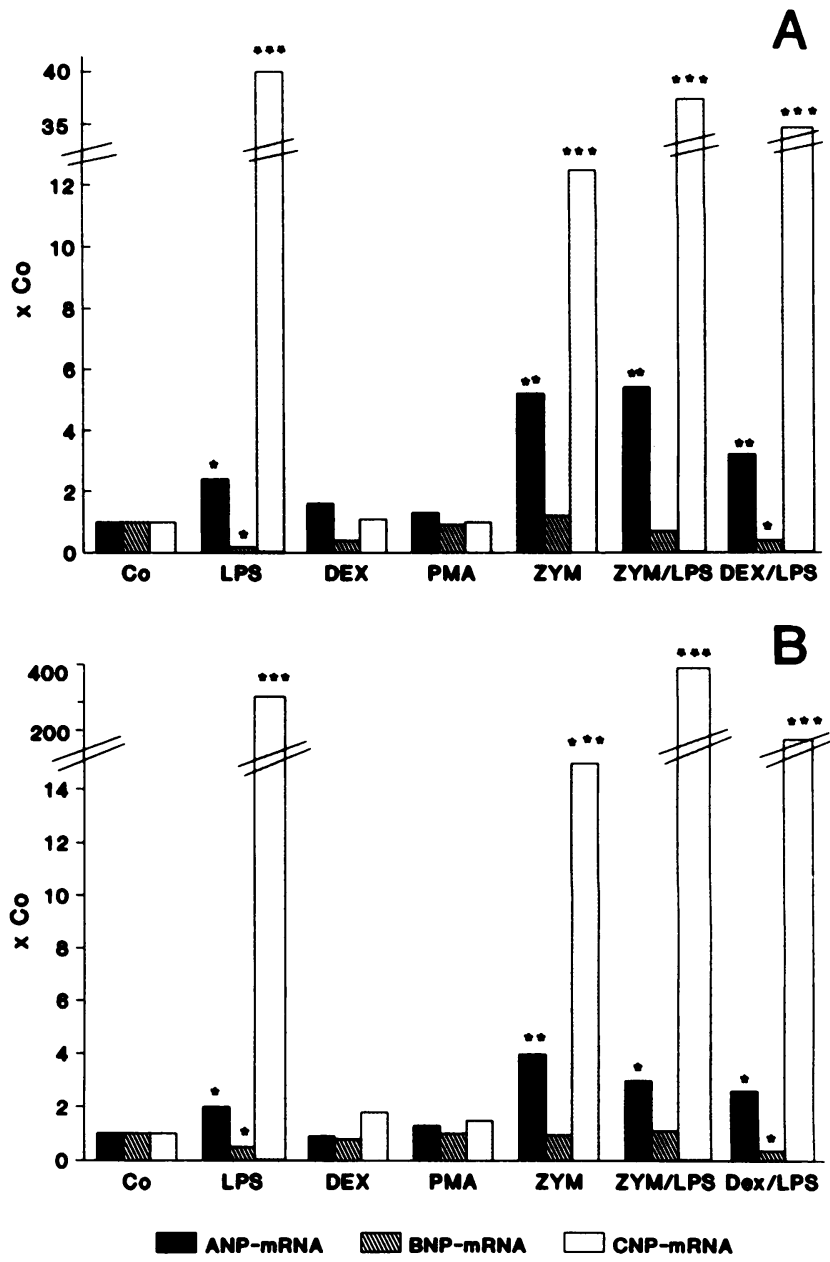

Figure 5. Relative ANP, BNP, and CNP mRNA levels in unstimulated PM $(A)$ and BMM $(B)$ as well as after stimulation with LPS, zymosan, Dex, PMA, LPS/Dex, and zymosan/LPS, respectively. Values are derived from titration curves (Fig. 4) of three independent experiments and are expressed as multifold of mRNA concentration of control cells $(x \mathrm{Co})$. Standard errors were $<20 \%$ and for the sake of clearness not incorporated. ${ }^{*} P<0.05,{ }^{*} P<<0.01,{ }^{*} * P<0.001$ (Student's $t$ test).

does not seem to be significantly stimulated yet, indicating a sequential activation of TNF- $\alpha$ and CNP expression.

Production and secretion of NP by BMM and PM. The peptides (IR) BNP (40 $\pm 11 \mathrm{pg} / \mathrm{mg}$ protein) and CNP (54 \pm 17 $\mathrm{pg} / \mathrm{mg}$ protein) were found together with ANP (26 $\pm 9 \mathrm{pg} / \mathrm{mg}$ protein) in PM and BMM as demonstrated by HPLC/RIA analysis. Loss of IR due to extraction and chromatographic procedures was in the range of $65 \%$ for BNP and $70 \%$ for CNP. Peptide concentrations given have been corrected for recovery (see Methods).

A representative HPLC profile of intracellular CNP-IR from BMM revealed CNP-22 as the major form of IR detected, accompanied by a small amount of CNP-53 (Fig. $9 \mathrm{~A}$ ). Exposure of BMM to LPS ( $1 \mu \mathrm{g} / \mathrm{ml}, 24 \mathrm{~h})$ results in a fivefold (265 564 $\mathrm{pg} / \mathrm{mg}$ protein, $n=3, P<0.01$ ) increase of CNP-22 (Fig. 9 $A$ ) and a twofold increase for ANP (53 $\pm 11 \mathrm{pg} / \mathrm{mg}$ protein, $n$ $=3, P<0.05$ ). BNP-IR from PM and BMM mainly relates to BNP-45, and no significant alteration of its concentration was 


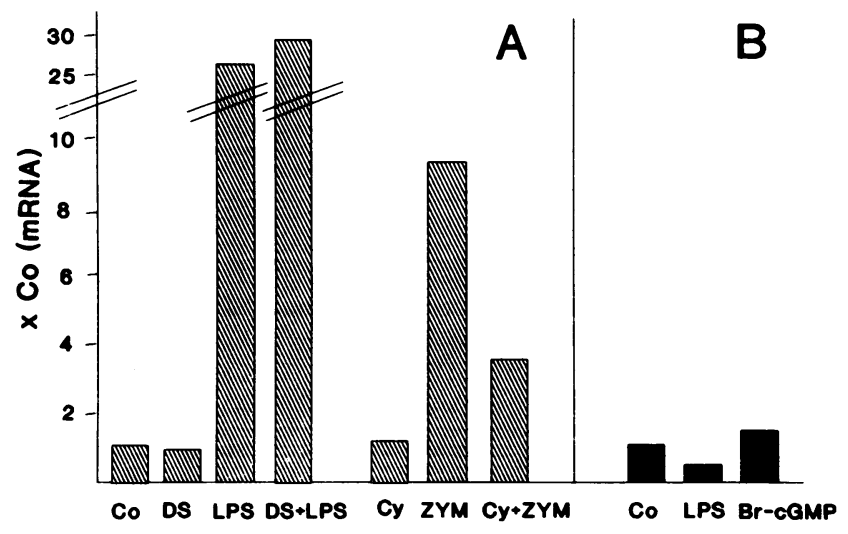

Figure 6. (A) Effect of inhibitors of scavenger receptors as well as of phagocytosis on stimulation of CNP expression. Cells were treated (18 h) with dextran sulfate $(D S, 10 \mu \mathrm{g} / \mathrm{ml})$ or cytochalasin $(C y, 25 \mu \mathrm{g} / \mathrm{ml})$ with or without LPS $(1 \mu \mathrm{g} / \mathrm{ml})$ and zymosan $\left(Z Y M, 10^{6}\right.$ cells $\left./ \mathrm{ml}\right)$, respectively. $(B)$ Influence of cGMP on BNP mRNA expression. Cells were exposed to either 8-Br-cGMP $(0.1 \mathrm{mM})$ or LPS $(1 \mu \mathrm{g} / \mathrm{ml})$ for 18 h. Relative mRNA concentrations are expressed as multifold of mRNA in untreated cells $(\mathrm{Co})$ and were calculated from competitive PCR analysis $(n=2)$ as described above, although different mRNA preparations were used.

observed upon stimulation with LPS ( $48 \pm 13 \mathrm{pg} / \mathrm{mg}$ protein, $n$ $=3$ ).

PM and BMM secrete all three NP. The released IRs do not differ in terms of their molecular weights from intracellularly extracted IRs as shown by HPLC analysis for CNP-IR separated from culture medium (Fig. $9 \mathrm{~B}$ ). The amount of IR found in the medium ( $24 \mathrm{~h}$ interval), however, exceeds that extracted from cells (PM/BMM) severalfold (ANP: $125 \pm 30 \mathrm{pg} / \mathrm{mg}$ cell protein; BNP: $96 \pm 16 \mathrm{pg} / \mathrm{mg}$ cell protein; CNP: $143 \pm 25 \mathrm{pg} / \mathrm{mg}$ cell protein). Stimulation of macrophages with LPS yielded a striking increase ( 10 -fold, $1,580 \pm 320 \mathrm{pg} / \mathrm{mg}$ protein, $P<0.01$ ) of secreted CNP material (Fig. $9 B$ ), whereas no effect was noted on the amount of released BNP-IR. Secretion of ANPIR was augmented 3.5-fold $(P<0.05)$ upon LPS, being in line with the reported data (17).

\section{Discussion}

This paper communicates two major findings. First, all three NP; ANP, BNP, and CNP are synthesized and secreted by peritoneal and bone marrow-derived macrophages of mice. Second, expression of the individual mRNAs coding for the NP as well as of the corresponding peptides are differently affected by exposure of macrophages to immunomodulatory compounds.

Macrophages are known to play a pivotal role in host defense mediated in part through the synthesis and release of numerous cytokines (33-35). The data given here suggest that NP represent such macrophage-derived mediators. In fact, this finding adds to the well known potency of macrophages to produce numerous peptide hormones (36). As for most of these peptides (36), little is known about functions of NP within the immune system. However, with respect to ANP some information is available as this peptide has been shown to enhance the cytotoxicity of natural killer cells (11), it appears to prime polymorphonuclear neutrophils secreting superoxide anions (10), and it suppresses the uptake of IgG complexes by macrophages (37).
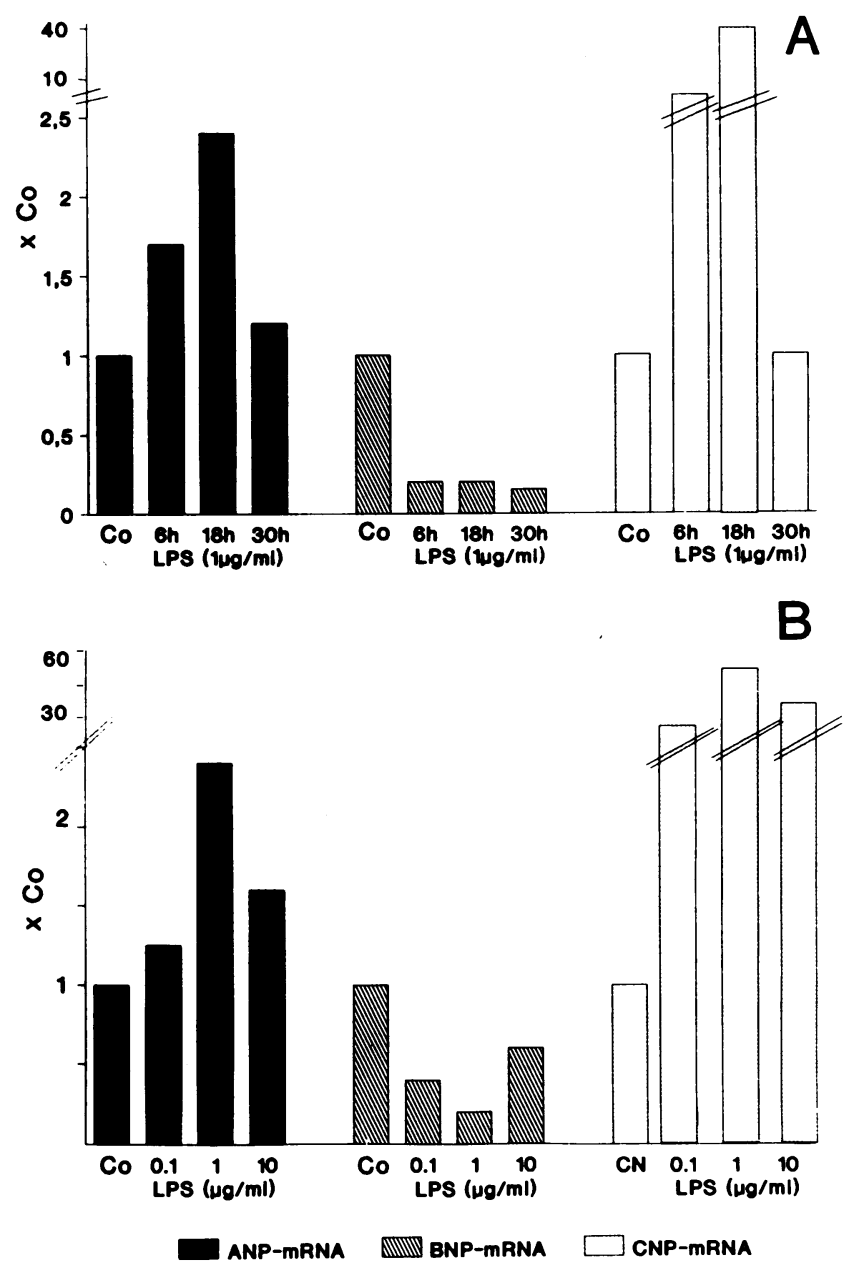

Figure 7. Effect of different time intervals of incubation $(A)$ and different concentration of LPS $(B)$ on relative ANP, BNP, and CNP mRNA concentration in BMM. Values were derived from titration curves as described in Fig. 6. Individual data represent the mean of two samples. Co, unstimulated cells.

The coexistence of the NP in macrophages suggests that all three peptides may be involved in modulation of immunological functions. The physiological selection between the three NP, however, may occur by way of differential regulation of their synthesis as suggested for NP in ventricular tissue $(21,22,38)$. Therefore, and in light of the fact that modulation of macrophage function is largely mediated by changes in gene expression $(33,34,39-41)$, the investigation of effects of activation of macrophages on NP expression was considered mandatory. Since data on NP mRNA concentrations were solely obtained by use of quantitative RT-PCR which represents a very sensitive, but also controversially discussed methodology, emphasis should be put on the mode of quantitation used here. The major criticisms of PCR quantitation are the high variability of the RT reaction, nonexponential amplification conditions depending both on the amount of cDNA used and the number of cycles, and, finally, variations in amplification efficiency $(29,30)$. Therefore, PCR protocols used for mRNA quantitation have to control for these major pitfalls. The combination of monitoring RT reaction and competitive PCR although time consuming, has shown here to be a reliable method at least for relative quantitation of mRNA concentrations. 


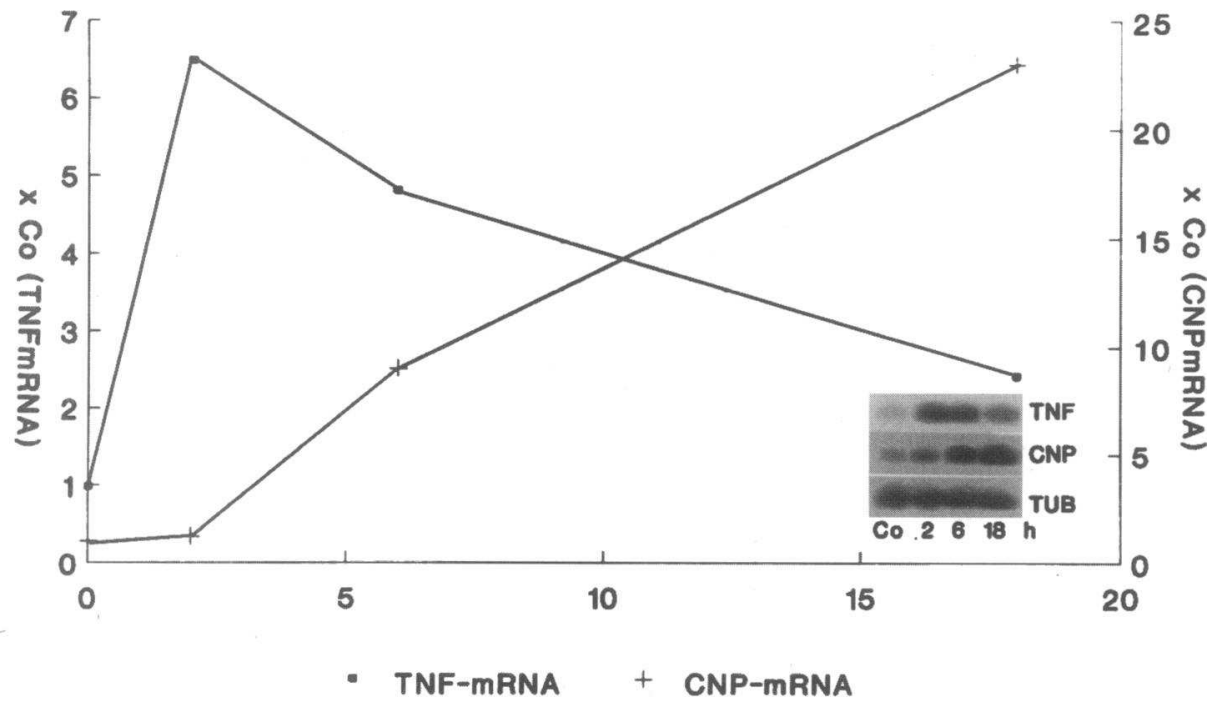

Figure 8. Representative time relation between TNF- $\alpha$ and CNP expression in BMM exposed to LPS. TNF- $\alpha$ and CNPspecific transcripts were amplified from cDNA ( 0.1 and $20 \mathrm{ng})$ derived from BMM incubated with LPS $(1 \mu \mathrm{g} / \mathrm{ml})$ for either 2,6 , or $18 \mathrm{~h}$. As control for similar amplification efficiency, PCR of tubulin (TUB) sequences was performed (5 pg cDNA). Inset shows a representative autoradiogram of TNF, CNP, and TUB PCR products. Experiment has been repeated twice yielding similar results.
IR-CNP (pg/tube)

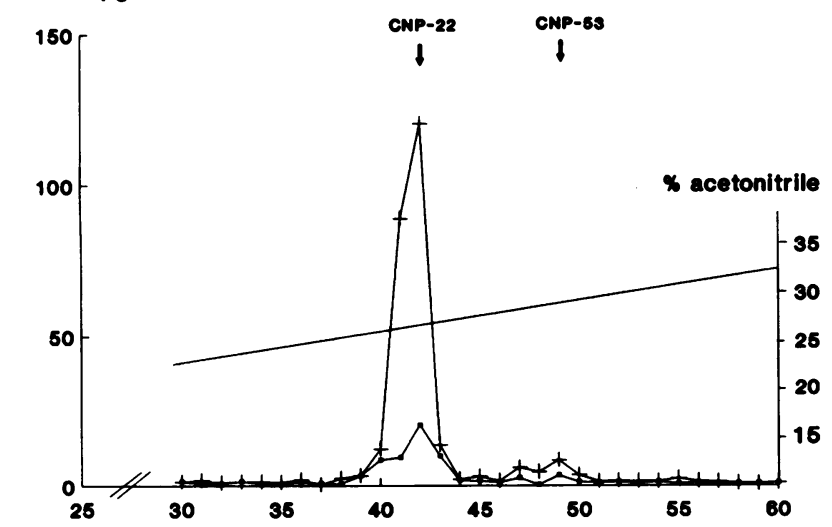

IR-CNP (pg/tube)

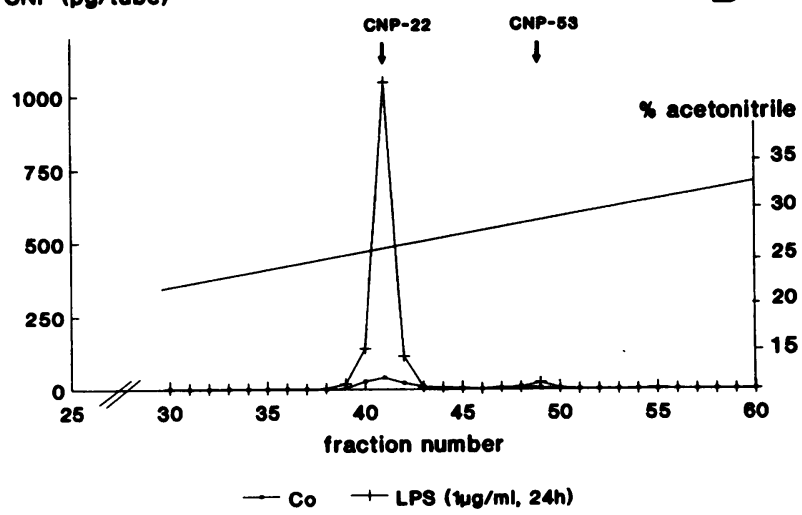

Figure 9. Representative HPLC-analysis of CNP-IR $(A)$ from extracts of BMM untreated ( $\square)$ or stimulated with LPS $(1 \mu \mathrm{g} / \mathrm{ml}, 24 \mathrm{~h})(+) . B$ shows the HPLC elution pattern of CNP-IR released from control cells (घ) as well as cells exposed to LPS $(+)$. The obtained fraction were assayed by RIA. Arrows indicate elution positions of synthetic CNP fragments. The experiment was repeated twice yielding similar results.
The striking effect of macrophage activation by the immunomodulators LPS or zymosan on the mRNA coding for CNP elucidated by this mode of PCR may be discussed with respect to the recently reported function of this peptide. CNP is suggested to act as a local mediator, which is produced by endothelial cells (8) and exerts an antiproliferative effect on smooth muscle cells (9). Moreover, CNP interferes with effects of growth factors as its synthesis in endothelial cells is strongly stimulated by TGF- $\beta$ (8) and CNP itself blocks the growth of muscle cells induced by growth factors $(9,42)$. These characteristics of CNP resemble features of a growth regulator which are shared by a number of cytokines and are important for various immunological processes (34). The documentation of CNP in a human monocyte cell line and the increased production after transformation of these cells to macrophages by phorbol ester (43) are in line with our data presented here and support the concept of a function of CNP in the immune system.

Another point which deserves attention is the seemingly selective activation of CNP mRNA by substances such as LPS or zymosan. The complex action of LPS $(33,35)$ to activate macrophages impedes the understanding of the underlying biochemical mechanisms with regard to stimulation of CNP production. One possibility, namely the involvement of the scavenger receptor pathway (29), has been shown to be less likely as receptor blockade (by dextran sulfate) did not attenuate the LPS effect on CNP mRNA. It is well known, however, that activation of macrophages by LPS results in an enhancement of mRNA levels for numerous immune mediators, including TNF and IL-1 $(33,39)$. The sequential activation of CNP mRNA expression in relation with TNF- $\alpha$ gene expression observed here, may suggest a direct effect of TNF- $\alpha$ on NP production by macrophages as reported for other cells $(8,43)$. The fact that PM respond to LPS with a 10-fold higher CNP expression as compared to BMM may be related to their different states of functional competence $(40,41)$. Furthermore, macrophages originating from different tissues have been shown to distinctly react to LPS as judged by their production of TNF- $\alpha$ (44).

The pronounced effect observed also for zymosan on CNP expression and moreover, its attenuation by exposure of cells 
to cytochalasin-B known to inhibit endocytosis suggests that activation of phagocytosis may at least be partly responsible for increased synthesis of CNP (32). Similar arguments apply to the ANP expression in PM and BMM upon exposure to immunomodulators (17). Expression of both NP seems to be concordantly regulated, though the effects observed for ANP are considerably lower as compared to CNP.

Interestingly, the concentration of mRNA coding for BNP in activated macrophages is decreased after LPS stimulation. It is well known that concentrations of mRNA may be regulated at multiple levels, such as their export from the nucleus degradation of mRNA and rate of transcription (45). In this respect two observations concerning NP gene regulation are noteworthy. First, differences among promoter sequences of ANP, BNP, and CNP have been identified suggesting a different regulation of NP gene transcription $(1,2)$. Second, the $3^{\prime}$ untranslated region ( $3^{\prime} \mathrm{UTR}$ ) of the BNP cDNA contains repeated sequences of TATTTAT and these arrangements have been linked to mRNA instability (45). It is tempting to speculate that the decrease of BNP mRNA in activated macrophages is related to these specific nucleotide sequences. In fact, transfection experiments have shown that cytokine constructs, such as TNF or IFN- $\beta$, bearing the $3^{\prime}$ UTR were degraded more rapidly after exposure to LPS or Dex $(46,47)$. Although experiments for testing turnover of mRNAs of NPs have not been performed yet, the distinct regulation of BNP mRNA in macrophages may indeed reflect a discordant regulation of BNP transcription as compared to ANP or CNP. Our experiments of exposure time and dose-dependency of the NP mRNA expression as well as the determination of the translational products further strengthen this notion. Since BNP mRNA decreases under circumstances when ANP and CNP expression is increased, one could also speculate that ANP and CNP might down-regulate expression of BNP via their second messenger $\operatorname{cGMP}(1,2)$. A stable analogue of cGMP, 8-bromo-cGMP, however, did not show any effect on BNP mRNA in BMM. On the other hand, ANP and CNP may mediate the decrease of BNP mRNA through the C-type receptor not coupled to guanylate cyclase (1-4). In any case, reports of expression of ventricular BNP mRNA in comparison to mRNA coding for ANP during fetal development (23) as well as in spontaneous hypertensive rats (22) confirm the notion of a discordant NP gene regulation. Moreover, BNP and ANP gene expression has been shown to be differently affected by atrial stretch (48). Recently, all three NP have also been identified in human ventricular tissue and circulating and cardiac concentration have been found to be differentially regulated in patients with congestive heart failure (38). Whereas ANP and BNP are produced by cardiac myocytes $(18,19)$, the cellular site of synthesis of CNP in the heart remains unclear (38). Thus, our data on macrophages, present for the first time, cells being able to express all three NP. It may be noteworthy that the genes of ANP and BNP are closely linked on chromosome 4 in mice (27). Although the localization of the CNP gene needs to be established, the possibility was raised that the NP genes are organized in a multigene locus, a feature which may be important for their individual transcriptional regulation (27).

The putative complexity of regulation of NP expression in macrophages demonstrated here is in accordance with the emerging concept of cytokine characteristics of NP. Gene regulation of cytokines in activated macrophages represents a complex response of enhanced and suppressed transcription or trans- lation depending on the kind of stimuli given and the gene examined (33-35, 39-41, 44).

According to the data presented here, NP may be added to the list of compounds known to be regulated upon macrophage activation. Further interest may focus on the issue whether the differential regulation of the NP in macrophages corresponds with distinct functions for each peptide.

\section{Acknowledgments}

We thank U. Rüberg, C. Siegl, and A. Wehlmeier for their excellent technical assistance.

This work was supported by the Deutsche Forschungsgemeinschaft (Vo-376/6-1).

\section{References}

1. Nakao, K., Y. Ogawa, S. Suga, and H. Imura. 1992. Molecular biology and biochemistry of the natriuretic system. I: Natriuretic peptides. J. Hypertens. 10:907-912.

2. Rosenzweig, A., and C. E. Seidman. 1991. Atrial natriuretic factor and related peptide hormones. Annu. Rev. Biochem. 60:229-255.

3. Jamison, R. L., S. Canaan-Kühl, and R. Pratt. 1992. Physiology and cell biology update. The natriuretic peptides and their receptors. Am. J. Kidney Dis. 20:519-523.

4. Nakao, K., Y. Ogawa, S. Suga, and H. Imura. 1992. Molecular biology and biochemistry of the natriuretic peptide system. II: Natriuretic peptide receptors. J. Hypertens. 10:1111-1114.

5. Gutkowska, J., and M. Nemer. 1989. Structure, expression and function of atrial natriuretic factor in extraatrial tissues. Endocr. Rev. 10:519-537.

6. Gerbes, A. L., L. Dagnino, T. Nguyen, and M. Nemer. 1994. Transcription of brain natriuretic peptide and atrial natriuretic peptide genes in human tissues. J. Clin. Endocrinol. \& Metab. 78:1307-1311.

7. Vollmar, A. M., A. L. Gerbes, M. Nemer, and R. Schulz. 1993. Detection of C-type natriuretic peptide (CNP) transcript in the rat heart and immune organs. Endocrinology. 132:1872-1874.

8. Suga, S. K., H. Itoh, Y. Komatsu, Y. Ogawa, N. Hama, T. Yoshimasa, and K. Nakao. 1993. Cytokine-induced C-type natriuretic peptide (CNP) secretion from vascular endothelial cells: evidence for CNP as a novel autocrine/paracrine regulator from endothelial cells. Endocrinology. 133:3038-3041.

9. Furuya, M., M. Yosida, Y. Hayashi, N. Ohnunma, N. Minamino, K. Kangawa, and H. Matsuo. 1991. C-type natriuretic peptide is a growth inhibitor of rat vascular smooth muscle cells. Biochem. Biophys. Res. Commun. 177:927931.

10. Wiedermann, C. J., M. Niedermühlbichler, and H. Braunsteiner. 1992. Priming of polymorphonuclear neutrophils by atrial natriuretic peptide in vitro. J. Clin. Invest. 89:1580-1586.

11. Moss, R. B., and M. C. Golightly. 1991. In vitro enhancement of natural cytotoxicity by atrial natriuretic peptide fragment 4-28. Peptides (Tarryt.). 12:851-854.

12. Vollmar, A. M., and R. Schulz. 1990. Atrial natriuretic peptide is synthesized in the human thymus. Endocrinology. 126:2277-2280.

13. Throsby, M., Z. Yang, D. Lee, W. Huang, D. L. Copolov, and A. T. Lim. 1993. In vitro evidence for atrial natriuretic factor- (5-28) production by macrophages of adult thymi. Endocrinology. 132:2184-2190.

14. Vollmar, A. M., and R. Schulz. 1990. Dexamethasone action on rat thymic atrial natriuretic peptide. Endocrinology. 127:3240-3242.

15. Vollmar, A. M., F. Colbatzky, and R. Schulz. 1993. Increased production of atrial natriuretic peptide in the rat thymus after irradiation. Immunopharmacology. 26:65-72.

16. Vollmar, A. M., F. Colbatzky, and R. Schulz. 1992. Expression of atrial natriuretic peptide in thymic macrophages after dexamethasone treatment of rats. Cell Tissue Res. 268:397-399.

17. Vollmar, A. M., and R. Schulz. 1993. Gene expression and secretion of atrial natriuretic peptide in murine macrophages. J. Clin. Invest. 94:539-545.

18. Hasegawa, K., H. Fujiwara, H. Itoh, K. Nakao, T. Fujiwara, H. Imura, and C. Kawai. 1991. Light and electron microscopic localization of brain natriuretic peptide in relation to atrial natriuretic peptide in porcine atrium. Immunohistocytochemical study using specific monoclonal antibodies. Circulation. 84:12031209.

19. Hira, G. K., I. R. Sarda, S. T. Wong, S. C. Pang, and T. G. Flynn. 1993. Immunoreactive iso-ANP/BNP in plasma, tissues and atrial granules of the rat. Regul. Pept. 44:1-9.

20. Herman, J. P., M. C. Langub, and R. E. Watson. 1993. Localization of 
C-type natriuretic peptide mRNA in rat hypothalamus. Endocrinology. 133:19031905.

21. Dagnino, L., J. P. Lavigne, and M. Nemer. 1992. Increased transcripts of B-type natriuretic peptide in spontaneously hypertensive rats. Quantitative polymerase chain reaction for atrial and brain natriuretic peptide transcripts. $H y$ pertension (Dallas). 20:690-700.

22. Takahashi, T., P. D. Allen, and S. Izumo. 1992. Expression of A-, B-, and C-type natriuretic peptide genes in failing and developing human ventricles. Correlation with expression of the Ca 2+ ATPase gene. Circ. Res. 71:9-17.

23. Stanley, E. R., D. M. Chen, and H. S. Lin. 1978. Induction of macrophage production and proliferation by a purified colony stimulating factor. Nature (Lond.). 274:168-170.

24. Parod, R. J., and J. D. Brain. 1983. Uptake of latex particles by macrophages: characterization using flow cytometry. Am. J. Physiol. 245:C220-C234.

25. Chirgwin, J. M., A. E. Przybyla, R. J. MacDonald, and W. J. Rutter. 1979. Isolation of biologically active ribonucleic acid from sources enriched in ribonuclease. Biochemistry. 18:5294-5299.

26. Seidman, C. E., K. Bloch, K. Klein, J. Smith, and J. Seidman. 1984 Nucleotide sequence of the human and mouse atrial natriuretic factor genes. Science (Wash. DC). 226:1206-1209.

27. Steinhelper, M. E. 1993. Structure, expression, and genomic mapping of the mouse natriuretic peptide type-B gene. Circ. Res. 72:984-992.

28. Kojima, M., N. Minamino, K. Kangawa, and H. Matsuo. 1990. Cloning and sequence analysis of a cDNA encoding a precursor for rat C-type natriuretic peptide (CNP). FEBS (Fed. Eur. Biochem. Soc.) Lett. 276:209-213.

29. Kolls, J., P. Deininger, J. C. Cohen, and J. Larson. 1993. cDNA equalization for reverse transcription-polymerase-chain reaction quantitation. Anal. Biochem. 208:264-269.

30. Gilliland, G., S. Perrin, K. Blanchard, and H. F. Bunn. 1990. Analysis of cytokine mRNA and DNA: detection and quantitation by competitive polymerase chain reaction. Proc. Natl. Acad. Sci. USA. 87:2725-2729.

31. Krieger, M., S. Acton, J. Ashkenas, A. Pearson, M. Penman, and D. Resnick. 1993. Molecular flypaper, host defense, and artherosclerosis. Structure, binding properties, and functions of macrophage scavenger receptors. J. Biol. Chem. 268:4569-4572.

32. Green, S. P., J. A. Hamilton, and W. A. Philips. 1992. Zymosan-triggered tyrosine phosphorylation in mouse bone marrow-derived macrophages is enhanced by respiratory-burst priming agents. Biochem. J. 288:427-432.

33. Adams, D. O., and T. A. Hamilton. 1984. The cell biology of macrophage activation. Annu. Rev. Immunol. 2:283-318.

34. Kelso, A. 1989. Cytokines: structure, function and synthesis. Curr. Opin. Immunol. 2:215-225.
35. Hamilton, T. A., and D. O. Adams. 1987. Molecular mechanisms of signal transduction in macrophages. Immunol. Today. 8:151-162.

36. Blalock, J. E. 1989. A molecular basis for bidirectional communication between the immune and the neuroendocrine systems. Physiol. Rev. 69:1-32.

37. Mattana, J., and P. C. Singhai. 1993. Effects of atrial natriuretic peptide and cGMP on uptake of IgG complexes by macrophages. Am. J. Physiol. 265:C92-C99.

38. Wei, C. M., D. M. Heublein, M. A. Perella, A. Lerman, R. J. Rodeheffer, C. G. A. McGregor, W. D. Edwards, H. Schaff, and J. C. Burnett. 1993. Natriuretic peptide system in human heart failure. Circulation. 88:1004-1009.

39. Yu, S. F., T. M. Koerner, and D. O. Adams. 1990. Gene regulation in macrophages activation: differential regulation of genes encoding for tumor necrosis factor, interleukin-1, JE, and KC by interferon- $\lambda$ and lipopolysaccharide. $J$. Leukocyte Biol. 48:412-419.

40. Gessani, S., U. Testa, B. Varano, P. Di Marzio, P. Borghi, L. Conti, T. Barberi, E. Tritarelli, R. Martucci, D. Seripa, et al. 1993. Enhanced production of LPS-induced cytokines during differentiation of human monocytes to macrophages. Role of LPS receptors. J. Immunol. 151:3758-3766.

41. Narumi, S., and T. A. Hamilton. 1991. Inducible expression of murine IP10 mRNA varies with the state of macrophage inflammatory activity. J. Immunol. 146:3038-3046.

42. Porter, J. G., R. Catalano, G. McEnroe, J. A. Lewicki, and A. A. Protter. 1992. C-type natriuretic peptide inhibits growth factor-dependent DNA synthesis in smooth muscle cells. Am. J. Physiol. 263:C1001-C1006.

43. Ishizaka, Y., K. Kangawa, N. Minamino, K. Ishii, S. Takano, T. Eto, and H. Matsuo. 1992. Isolation and identification of C-type natriuretic peptide in human monocyte cellline, THP-1. Biochem. Biophys. Res. Commun. 189:697704

44. Gardner, C. R., P. J. Lapinskas, L. S. Feder, and D. J. Laskin. 1989. Differential production of tumor necrosis factor by rat liver, lung and peritoneal macrophages. J. Leukocyte Biol. 46:340-351.

45. Sham, G., and R. Kamen. 1986. A conserved AU sequence from the 3' untranslated region of GM-CSF mRNA mediates selective mRNA degradation. Cell. 46:659-667.

46. Han, J., B. Beutler, and G. Huez. 1991. Complex regulation of tumor necrosis factor mRNA turnover in lipopolysaccharide-activated macrophages. Biochim. Biophys. Acta. 1090:22-31.

47. Peppel, K., J. M. Vinci, and C. Baglioni. 1991. The AU-rich sequences in the $3^{\prime}$ untranslated region mediate the increased turnover of interferon mRNA induced by glucocorticoids. J. Exp. Med. 173:349-356.

48. Mantymaa, P., O. Vuolteenaho, M. Marttila, and H. Ruskoaho. 1993. Atrial stretch induces rapid increase in brain natriuretic peptide but not in atrial natriuretic peptide gene expression in vitro. Endocrinology. 133:1470-1473. 